regular but they are not concentric with the standing circle nor in relation to themselves. The distance from the outer circle gradually diminishes from where they begin at the entrance until No. 8 is reached, after which they take up the original distance; this applies to both circles. Some confusion was noted where the irregularities terminated; No. 7 hole had been only partly dug, and Z8 was found not to exist.

It can be clearly proved that these holes were made in the Stonehenge period, because the mason's chips were present in the filling and even upon the bottom. The first four holes excavated occur in the fairway from the entrance, and it may be safely said that they never held stones. Although dug for the purpose, consideration afterwards led them to leave the holes empty, as the stones would have been inconvenient in the fairway. Their sharpness and undisturbed condition showed there had been no insertion and extraction of stones; moreover, one of them contained five stag antlers and another a single antler, showing absence of stones. The other holes showed disturbances caused by extracting stones. Soil had fallen back, partly filling the holes, and over it was a more recent stratum bearing objects from the time of extraction to the present day. Romano-British objects were found in the upper stratum, and in one hole, about 18 to 20 inches from the top, there was dirty soil mixed with wood ashes and some natural flints arranged apparently as a temporary hearth, and on the same level were 42 pieces of a Romano-British pot. A little below this level were three pieces of fine, gritty pottery belonging to the "La Tene" period. This gives the impression that the stone was extracted at that time, and that spoliation on the site might have begun at quite an early date.

Where the irregularity occurred at No. 8, a considerable area was opened out to try to discover a reason for it, but with not much success. A great many post holes were met with, and, since then, a still greater number have been found extending from this spot towards the rampart, some of them taking the form of parallel lines; these are now in course of investigation. They are evidently of quite early date, as the Stonehenge stratum passes over them and they contain nothing of that period. Eleven of them, about
6 feet apart, formed a long row, the last two holes at one end having been united by digging to form a grave at a time when posts no longer stood there, the holes and loose matter affording less trouble in digging one. A skeleton found in it proved to be that of a person belonging to a long-headed race existing shortly before the Roman occupation. Owing to insufficient length and capacity of the grave (barely 3 feet deep) the remains were much crushed, but have nevertheless been reconstructed.

Remains of the Bronze age do not occur until after the erection of Stonehenge and are found in the upper stratum consisting chiefly of foot-worn fragments of pottery. With a cremation of that period there was found a beautifully ground and polished mace head of the "cushion" type. The stone is hornblendic gneiss and probably came from Brittany. Eight other specimens are known to exist of that type, now in collections, five of them coming from Scotland and three from the Thames and its neighbourhood, and they are regarded as ceremonial maces of that period. With another cremation a very fine bone pin 7 inches long was found. It had been burnt with the body and was much twisted by heat and broken in three places, but was easily mended. The cremated remains are usually found but a short distance below ground, most of them actually without cists in the loose chalk rubble at the foot of the rampart; sometimes the remains are found clinging to a turf when it is cut and turned over. This shows that the rampart conditions cannot have been very different then from what we see them now. The impression created during the continuance of excavation here makes one aware that a long succession of events is being dealt with which have covered a vast number of years. The silting of the main ditch alone is a proof of this. This process must have taken a very long time, for sometimes there are 6 feet of it and not a vestige of the Stonehenge era occurs in it, and is only met with as a narrow stratum below the turf and abruptly divided from it. Unfortunately, none of these matters have as yet given any information as to the date of the monument, but there is yet a great deal of ground to be opened, and by more time and diligent search it is hoped eventually to arrive at some clear conclusions.

\title{
Circumnavigation of the Earth by Aeroplane.
}

$\mathrm{O}^{\mathrm{N}}$ April 6, four U.S.A. aeroplanes left Seattle on an air voyage of circumnavigation of the world. Five months later, on September 6, two out of the four arrived at Boston. Flying took place on 48 days out of I53 days thus consumed. The actual flying hours were 288 ; the distance covered was $2 \mathrm{I}, 500$ miles. About every third day on the average was therefore a flying day of 6 hours flying at 75 miles per hour, giving a flying day's run of 450 miles.

The flight falls naturally into four stages, floats being fitted for stages I and 3 , wheels for 2 and 4 . New engines were fitted at the start, and in Japan, at Calcutta, and at Hull. New wings were fitted at Calcutta, and numerous subsidiary repairs and replacements were carried out. Cruisers, supply ships, and flotillas of destroyers were employed in the improvised organisation along the sea routes. Existing permanent organisations were available along the land routes.

In stage I the route runs along the Pacific Coast of Canada and Alaska, and_crosses the northern entrance of the Pacific Ocean by the Aleutian Islands; thence it runs by Kamchatka and Japan round the Chinese and Burmese coast to Calcutta. The Aleutian Islands, in which aeroplane No. I fell out, are subject to fogs, squalls and blizzards, the Chinese seas to typhoons, and the southern arc, Saigon-Rangoon, to tropical heats. There is no permanent airway organisation in the first part of this stage, and in the second part the Japanese, French and British organisations are not continuous. In this stage as a whole, flying took place only on 22 days out of 82 , Ir, 000 miles being covered in ${ }^{1} 5^{8}$ flying hours.

At Calcutta 4 days were spent in fitting new engines, new wings, and wheels for the overland stage Calcutta-

$$
\text { NO. 2864, VOL. I I } 4 \text { ] }
$$


London. Leaving Calcutta on July $\mathrm{I}$ and arriving at Hull on July 17 , the aeroplanes flew on $I_{5}$ days out of $I 7$, covering a distance of 6500 miles in 74 flying hours. The advantage of a permanent ground organisation is evident, and to this is added the inherent advantage of wheels over floats in both weight and air resistance.

At Hull I I days were spent in overhauling the aeroplanes and in fitting new engines, and floats for the passage of the northern entrance of the Atlantic by way of the Orkneys, Faroë Islands, Iceland, Greenland and Labrador. Leaving Hull on July 30 , and arriving at Boston on September 6, the aeroplanes flew on II days out of 39,4000 miles being covered in $5^{6}$ flying hours. Aeroplane No. 3 fell out between the Orkneys and Iceland. The remaining stage is from Boston via New York to Washington, thence due west to Salt Lake City, and so back to Seattle. Fitted with wheels, and using a homogeneous national air organisation, there is high probability that the two surviving aeroplanes will complete expeditiously the circumnavigation of the earth by air, except in so far as they are detained by the hospitality of their countrymen at the landing places.

In drawing technical conclusions from the flight, no account can be taken of the great personal effort of the pilots and mechanics in thus facing successfully every sort of condition along 24,000 miles of route, unknown to them. The quasi-sporting condition that the same aeroplane bodies should circle the earth albeit with new engines, wings and other parts is also irrelevant. In a strictly utilitarian organisation fresh machines and pilots familiar with the route would be available for each 5-hour stage, and two such stages a day would be feasible. When it is found possible to maintain permanent airway organisation along such regions as the northern entrances of the Atlantic and Pacific Oceans, it may become possible, flying ro hours a day at too miles per hour, to circumnavigate the world by air in about 24 days as a matter of routine travelling.

\section{Obituary.}

\section{Mr. Hartley Lupton.}

$B^{\mathrm{Y}}$ $\mathrm{Y}$ the death on September 6 of Mr. Hartley Lupton, at the early age of thirty-two years, physiology has lost a research worker of great industry and promise, his pupils a teacher who won their respect by his care and keenness and their affection by his simplicity and kindness, his friends at Manchester and at University College, London, a generous and devoted colleague. For generosity, simplicity, and devotion were the keynotes of Lupton's life. Stricken with a fatal illness in June, he spoke continually of returning to his beloved apparatus in a few weeks. Only a month before his death, at a time of great discomfort and distress, he read with appreciation and delight the manuscripts of three papers shortly to appear in the Proceedings of the Royal Society, describing the results of three years of devoted work. Rarely, until his last illness had completely incapacitated him, was he absent from the laboratory: he arrived first in the morning, he left last at night; he was always ready for any new experiment, any new enterprise, any extra work.

Lupton had an extraordinary capacity for friendship with young men, a capacity which served him well as a tutor at Dalton Hall, Manchester, and later in his physiological research work, where he continually needed "subjects" for his experiments. All who knew him will recall the pleasant and humorous picture of Lupton engaged in some experiment on severe muscular work, either on himself or some friend whom he had induced to take (at any rate temporarily) a sufficient interest in physiology to act as the subject of his-often rather strenuous-experiments. His own personal devotion can be gauged from the frequent entry " Subject, H. L. postabsorptive" in his records.

Lupton obtained a first-class honours degree in physics at the University of Manchester: the outlook of the physicist remained with him in his later work, and led to the scrupulous accuracy which is seen in all the records of his observations. His first independent scientific task was the routine work with radium at the Manchester Royal Infirmary. His experience there led his questioning mind to ask for the reason why radioactive bodies should have the effect they do on living tissues: the next step was to decide to take a medical degree, and it was as a student of physiology that the present writer first made his acquaintance. His teachers soon realised that Lupton was a person of rather singular interests and capacity, and an early opportunity occurred of starting him on physiological research. Working for the Medical Research Council, he took up the study of muscular exercise in man, based on the results of recent investigations of the isolated muscle. The subject proved fertile beyond expectation, and the results of it are contained in several papers published in the Quarterly Journal of Medicine, the Journal of Physiology, and the Proceedings of the Royal Society. When he began this work, three years ago, little was known of the connexion between the physiology of the muscle and that of human muscular exercise. Three years of continual labour-years probably the happiest of his life, for he was never so happy as when "going all out"--have discovered and explored a new subject, the important one of the recovery process after muscular effort in man. To the physiological world the subject will remain, one may hope, associated with his name: to his colleagues it will always recall the unceasing devotion and the simple kindness of their friend.

A. V. H

Prof. B. I. Slovzov, professor of biochemistry in the University of Saratov, and later in the Medical School for Women, Petrograd, whose death is announced, was a pupil of A. Kossel and A. Danilevsky and is known mainly for his contributions to the study of tissue enzymes. Another Russian man of science who has died recently is Prof. N. P. Kravkov, professor of pharmacology in the Medical Academy, Petrograd. Prof. Kravkov was a pupil of Schmiedeberg, and his chief work was performed on isolated organs which he used mainly for investigating the action of drugs upon blood-vessels. His method of the isolated rabbit's ears for testing vasoconstrictor and vasodilator substances is known universally and used in every pharmacological laboratory. Lately he contributed interesting observations upon the coronaries of the human heart and the isolated human fingers. He had been interested in the past few years in the action of drugs in highiy diluted solutions.

NO. 2864 , VOL. I I 4 ] 